\title{
Heterogeneity within Human-Derived Centers for Disease Control and Prevention (CDC) Coryneform Group ANF-1-Like Bacteria and Description of Corynebacterium auris sp. nov.
}

\author{
GUIDO FUNKE, ${ }^{1 *}$ PAUL A. LAWSON, ${ }^{2}$ AND MATTHEW D. COLLINS ${ }^{2}$ \\ Department of Medical Microbiology, University of Zurich, CH-8028 Zurich, Switzerland, ${ }^{1}$ and Department \\ of Microbiology, BBSRC Institute of Food Research, Reading Laboratory, \\ Reading RG6 6BZ, United Kingdom ${ }^{2}$
}

\begin{abstract}
Recently, Centers for Disease Control and Prevention coryneform group ANF-1 bacteria were described as Corynebacterium afermentans, and group ANF-1-like bacteria were described as Turicella otitidis. Over a 1.5-year period 10 strains of a previously undescribed, gram-positive, rod-shaped organism that was not partially acid fast and resembled ANF-1-like bacteria were isolated from different pediatric patients with ear infections. These previously undescribed coryneform bacteria exhibited a distinct colony morphology and consistency, had a carbon source utilization pattern distinct from the carbon source utilization patterns of $C$. afermentans and T. otitidis, had a cell wall based on meso-diaminopimelic acid, contained mycolic acids, and had DNA G+C contents of 68 to $74 \mathrm{~mol} \%$. A $16 \mathrm{~S}$ rRNA gene sequence analysis revealed that these clinical isolates are members of the genus Corynebacterium and that they are distinct from $C$. afermentans and $T$. otitidis. On the basis of phenotypic and phylogenetic evidence we propose a new species, Corynebacterium auris, for these Centers for Disease Control and Prevention coryneform group ANF-1-like bacteria. The type strain is strain DSM 44122 (CCUG 33426).
\end{abstract}

In the last few years, numerous studies have focused on the taxonomy of irregular gram-positive rods (IGPR) as the clinical significance of these bacteria has become more apparent (3). The extensive diagnostic charts created by Hollis and Weaver were the basis of many of these investigations (10); these charts enabled clinical microbiologists to approach the IGPR more systematically. Among the numerous taxa defined by Hollis and Weaver were the Centers for Disease Control and Prevention (CDC) coryneform absolute nonfermenting group 1 bacteria (group ANF-1). Recently, the CDC coryneform group ANF-1 bacteria have been shown to belong to two species, Corynebacterium afermentans (group ANF-1 [17]) and Turicella otitidis (group ANF-1-like $[8,9,21]$ ). Over an 18month period (February 1993 to July 1994) 10 strains tentatively identified as CDC group ANF-1-like bacteria were isolated by workers in the Department of Medical Microbiology at the University of Zurich (DMMZ) from different pediatric patients with ear infections. As the morphology and colony appearance of these clinical isolates were distinct from the morphology and colony appearance of $C$. afermentans and $T$. otitidis, we characterized them by using a number of phenotypic and molecular taxonomic techniques. On the basis of the findings of these investigations we formally propose a new Corynebacterium species, Corynebacterium auris, for these previously undescribed IGPR.

\section{MATERIALS AND METHODS}

Strains. Specimens from patients with ear infections (four patients with acute otitis media and six patients with chronic otitis media as determined clinically) were cultured on Columbia agar (Becton Dickinson, Cockeysville, Md.) supplemented with $5 \%$ sheep blood at $37^{\circ} \mathrm{C}$ in a $5 \% \mathrm{CO}_{2}$ atmosphere for up to $48 \mathrm{~h}$. The strains obtained were subcultured under the same conditions for $24 \mathrm{~h}$.

${ }^{*}$ Corresponding author. Mailing address: Department of Medical Microbiology, University of Zurich, Gloriastr. 32, CH-8028 Zurich, Switzerland. Phone: 41-1-257-2700. Fax: 41-1-252-8107.
Staphylococcus aureus ATCC 25923 was used to determine the results of the CAMP reaction.

Biochemical profiles. Traditional media were prepared as described previously (7). Commercial API Coryne and API ZYM systems (API bioMérieux, Marcy l'Etoile, France) were used according to the guidelines of the manufacturer. Utilization of carbohydrates was determined with BIOLOG GP plates (Biolog, Inc., Hazelwood, Calif.). Cells were grown on BUG medium (Biolog) supplemented with $5 \%$ sheep blood at $35^{\circ} \mathrm{C}$ for $24 \mathrm{~h}$. A bacterial suspension $\left(4.5 \times 10^{8}\right.$ cells per $\mathrm{ml}$ ) was prepared in $0.85 \% \mathrm{NaCl}$, and each GP plate was inoculated with $150 \mu \mathrm{l}$ of the suspension per well. The plates were incubated at $35^{\circ} \mathrm{C}$ for $24 \mathrm{~h}$ and then read automatically with a model MR5000 reader (Dynatech, Embrach, Switzerland).

Antimicrobial agent susceptibility tests. A standard set of antimicrobial agents (ciprofloxacin, clindamycin, erythromycin, gentamicin, penicillin $\mathrm{G}$, rifampin, tetracycline, and vancomycin) which are used to treat infections caused by IGPR was used to test the previously undescribed coryneform bacteria. The methods used for performance (agar dilution) and the methods used to interpret the data were the methods recommended by the National Committee for Clinical Laboratory Standards $(14,15)$.

Chemotaxonomic investigations. Cellular fatty acid patterns were determined with a MIDI system (Microbial ID, Inc., Newark, Del.) as described by von Graevenitz et al. (23). Whole-cell hydrolysates were examined for the presence of meso-diaminopimelic acid and mycolic acids by thin-layer chromatography (20). The method of Mesbah et al. (13) was used to determine the $\mathrm{G}+\mathrm{C}$ contents of the bacteria.

$16 \mathrm{~S}$ rRNA gene analysis. A large fragment of the 16S rRNA gene of strains DMMZ $328^{\mathrm{T}}$ ( $\mathrm{T}=$ type strain), DMMZ 355 , and DMMZ 399 was amplified by PCR by using universal primers pA (5'-AGAGTTTGATCCTGGCTCAG; positions 8 to 27 [Escherichia coli numbering]) and $\mathrm{pH}^{*}$ (5'-AAGGAGGTGATC CAGCCGCA; positions 1541 to 1522) as previously described (11). Purified PCR products were sequenced with a Taq DyeDeoxy terminator cycle sequencing kit (Applied Biosystems, Inc., Foster City, Calif.) and an Applied Biosystems model 373A automatic sequencer.

The 16S rRNA sequences which we determined were aligned with the sequences of reference organisms by using the program PILEUP (4), and the alignments were corrected manually. A phylogenetic tree was constructed by using the neighbor-joining method (18).

Nucleotide sequence accession number. The nucleotide sequence of the $16 \mathrm{~S}$ rRNA of strain DMMZ $328^{\mathbf{T}}$ has been deposited in the EMBL Data Library under accession number X82493.

\section{RESULTS AND DISCUSSION}

Between February 1993 and July 1994, 10 strains of a previously undescribed IGPR were isolated in pure culture from 
TABLE 1. Reactions that differentiate $C$. auris, C. afermentans, and T. otitidis

\begin{tabular}{lccc}
\hline \multicolumn{1}{c}{ Substrate } & \multicolumn{3}{c}{ Utilization by $^{a}$ : } \\
\cline { 2 - 4 } & C. auris & C. afermentans & T. otitidis \\
\hline Dextrin & - & + & - \\
D-Fructose & - & + & - \\
$\alpha$-D-Glucose & - & + & - \\
Maltose & - & + & - \\
D-Mannose & - & + & - \\
L-Rhamnose & - & + & - \\
D-Ribose & - & + & - \\
$\gamma$-Hydroxybutyric acid & + & - & + \\
L-Malic acid & + & + & - \\
Pyruvic acid & + & + & - \\
Succinamic acid & + & + & - \\
$N$-Acetyl-L-glutamic acid & + & + & - \\
L-Asparagine & + & + & - \\
L-Glutamic acid & + & + & - \\
Glycyl-L-glutamic acid & + & + & - \\
L-Pyroglutamic acid & + & + & - \\
Adenosine & - & &
\end{tabular}

${ }_{-}$, negative; + , positive

different patients (ages, 2 to 10 years; five females and five males) with ear infections by workers in the Department of Medical Microbiology at the Zurich University Hospital. These bacteria did not exhibit partial acid fastness. The results of biochemical screening reactions (nitrate reduction negative, urea hydrolysis negative, esculin hydrolysis negative, no acidification in cystine-Trypticase agar medium of glucose, maltose, sucrose, mannitol, and xylose) were consistent with assignment to CDC coryneform group ANF-1 (10). Interestingly, all 10 strains exhibited a strongly positive CAMP reaction, as has been observed for some strains of $C$. afermentans and all strains of $T$. otitidis $(5,8)$. However, the colony appearance and consistency (weak adherence to agar) of the new IGPR differed from the colony appearance and consistency of $C$. afermentans and $T$. otitidis, whose colonies are creamy. Therefore, we investigated further in order to establish the precise taxonomic position of the previously undescribed IGPR.

The abilities of the previously undescribed IGPR and of $C$. afermentans and $T$. otitidis strains to utilize certain carbohydrates were determined with the API $50 \mathrm{CH}$ system by using AUX medium as described previously (6). Because the previously undescribed IGPR, $C$. afermentans, and $T$. otitidis were not reactive in this system, the BIOLOG identification system, which has been used successfully to identify gram-positive aerobic bacteria (12), was employed. Strains of all three taxa (including the 10 strains described in this paper) utilized acetic acid, $\alpha$-hydroxybutyric acid, L-lactic acid, mono-methyl succinate, succinic acid, and L-serine. Characteristics that distinguish the three taxa are shown in Table 1. Our phenotypic data clearly indicated that the clinical isolates may represent a new taxon.

All 10 strains of the previously undescribed taxon were susceptible to ciprofloxacin, gentamicin, rifampin, tetracycline, and vacomycin but resistant to penicillin $\mathrm{G}$ (when the categories for staphylococci were used [15]). Five strains exhibited intermediate levels of susceptibility to clindamycin and erythromycin, and only one strain was resistant to erythromycin. The antimicrobial agent susceptibility patterns of $T$. otitidis are similar; in this species lower levels of susceptibility to clindamycin, erythromycin, and penicillin $\mathrm{G}$ are also common (5).

The cell wall of the previously undescribed IGPR contained meso-diaminopimelic acid as the diamino acid of the peptidoglycan. Mycolic acids were also detected, thereby distinguishing the previously undescribed IGPR from $T$. otitidis (9). The chemotaxonomic data for the previously undescribed IGPR that was not partially acid fast were compatible with assignment to the genus Corynebacterium. An analysis of the cellular fatty acids revealed that palmitic acid ( 14 to $34 \%$ of all cellular fatty acids), stearic acid ( 8 to $21 \%$ ), and oleic acid ( 30 to $58 \%$ ) were the predominant cellular fatty acids; no tuberculostearic acid, which is generally present in $T$. otitidis $(8,9)$, was detected. With the MIDI system we were able to identify only between 46 and $73 \%$ of the cellular fatty acids in the 10 strains which we examined. The system tentatively identified some fatty acids as pentadecanoic acid $\left(\mathrm{C}_{15: 0}\right)$, margaric acid $\left(\mathrm{C}_{17: 0}\right)$, and cis-heptadec-6 (to 9)-enoic acid $\left(\mathrm{C}_{17: 1 \text { (wo }}\right.$ to (1)\%); these tentatively identified fatty acids may have been, in fact, degradation products of mycolic acids which were cleaved at the temperature produced in the injection port of the system $\left(300^{\circ} \mathrm{C}\right)(19)$. We did not further analyze (e.g., by mass spectrometry [2]) the molecular structures of the mycolic acids present in the previously undescribed IGPR, but in our experience cleaved mycolic acids normally account for only between 2 and $10 \%$ of all cellular fatty acids of Corynebacterium strains when the compounds are analyzed with the MIDI system.

The observed $\mathrm{G}+\mathrm{C}$ contents of the 10 strains which we examined ( 68 to $74 \mathrm{~mol} \%$ ) were not within the generally accepted range for Corynebacterium species (51 to $63 \mathrm{~mol} \%$ ) (1). However, $\mathrm{G}+\mathrm{C}$ contents higher than $63 \mathrm{~mol} \%$ have been reported in strains of several Corynebacterium species, including C. afermentans ( 66 to $68 \mathrm{~mol} \%$ ) (17), Corynebacterium bovis $(68$ to $74 \mathrm{~mol} \%)(16,17)$, and Corynebacterium cystitidis $(70$ mol\%) (16). Therefore, our data provide further evidence that the range of $\mathrm{G}+\mathrm{C}$ contents for the genus Corynebacterium sensu stricto should be 46 (Corynebacterium kutscheri [16]) to $74 \mathrm{~mol} \%$. In comparison with other genera, this range of $\mathrm{G}+\mathrm{C}$ contents (about $28 \mathrm{~mol} \%$ ) is quite large and reflects considerable genotypic diversity within the genus Corynebacterium sensu stricto.

The almost-complete 16S rRNA gene sequence of a representative strain (DMMZ $328^{\mathrm{T}}$ ) of the clinical IGPR was determined. A comparison of the sequence which we determined with the sequences of other high- $\mathrm{G}+\mathrm{C}$-content actinomycetes (obtained from the EMBL Data Library) revealed that the highest levels of sequence similarity were with Corynebacterium species (approximately 93 to 96\%) (Table 2). Significantly lower levels of sequence similarity were found with members of the related genera Mycobacterium, Nocardia, Gordona, Rhodococcus, and Tsukamurella. An unrooted tree constructed from a matrix of sequence similarity values is shown in Fig. 1, and this tree clearly demonstrates that the previously undescribed IGPR are members of the genus Corynebacterium. It was evident from both sequence divergence considerations and the treeing analysis results that strain DMMZ $328^{\mathrm{T}}$ is genealogically distinct from previously described group ANF-1-like species (C. afermentans and $T$. otitidis exhibit approximately 96 and $93 \%$ sequence similarity with DMMZ $328^{\mathrm{T}}$, respectively) (22). The partial 16S rRNA gene sequences (approximately 500 bases, including variable regions V1 to V3) of two other clinical isolates (DMMZ 355 and DMMZ 399) were also examined and were found to be identical to the strain DMMZ $328^{\mathrm{T}}$ sequence, thereby confirming the genotypic similarity of these organisms.

On the basis of the phenotypic and molecular findings presented in this paper, we formally propose a new Corynebacterium species, Corynebacterium auris for the 10 clinical IGPR 


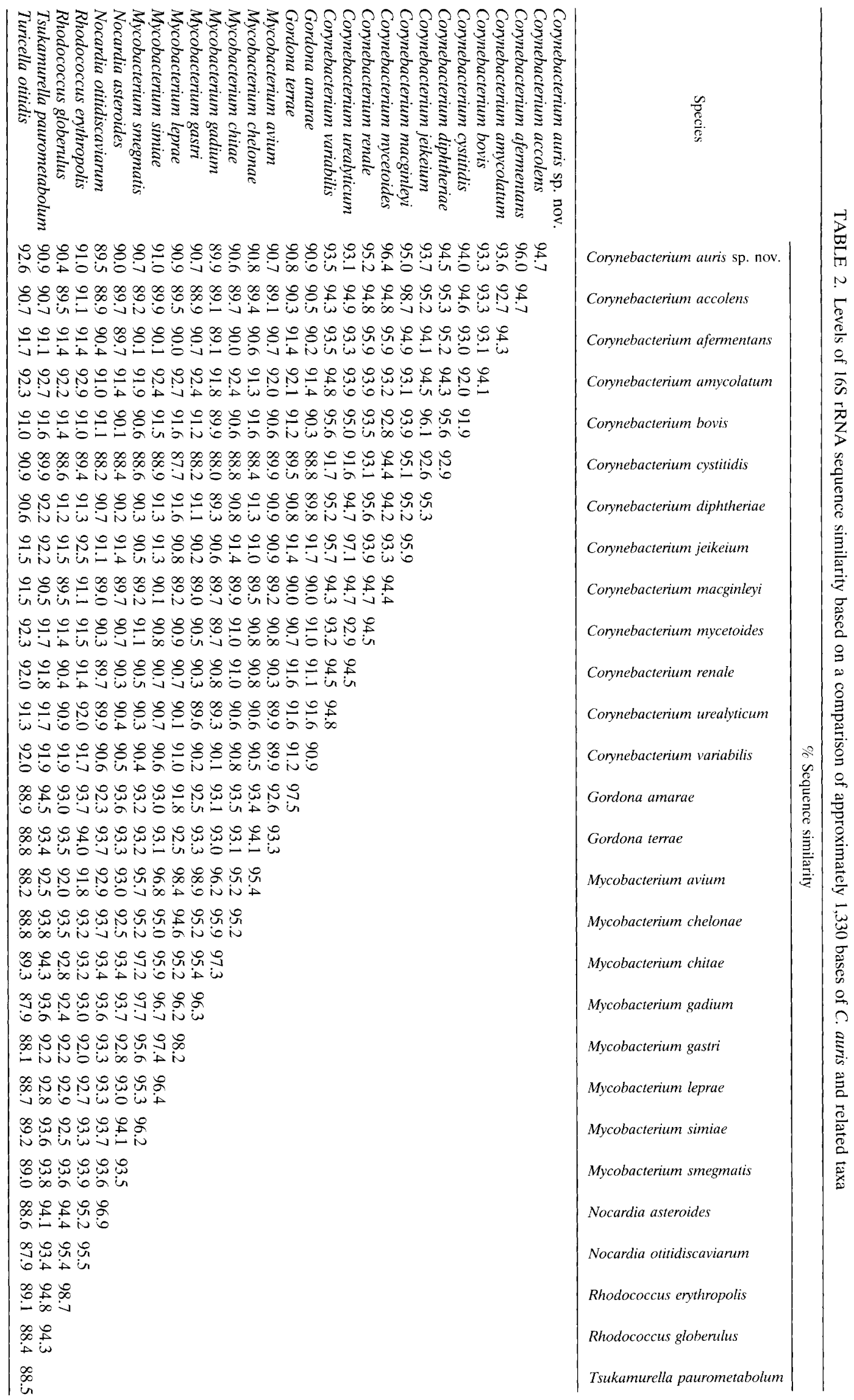




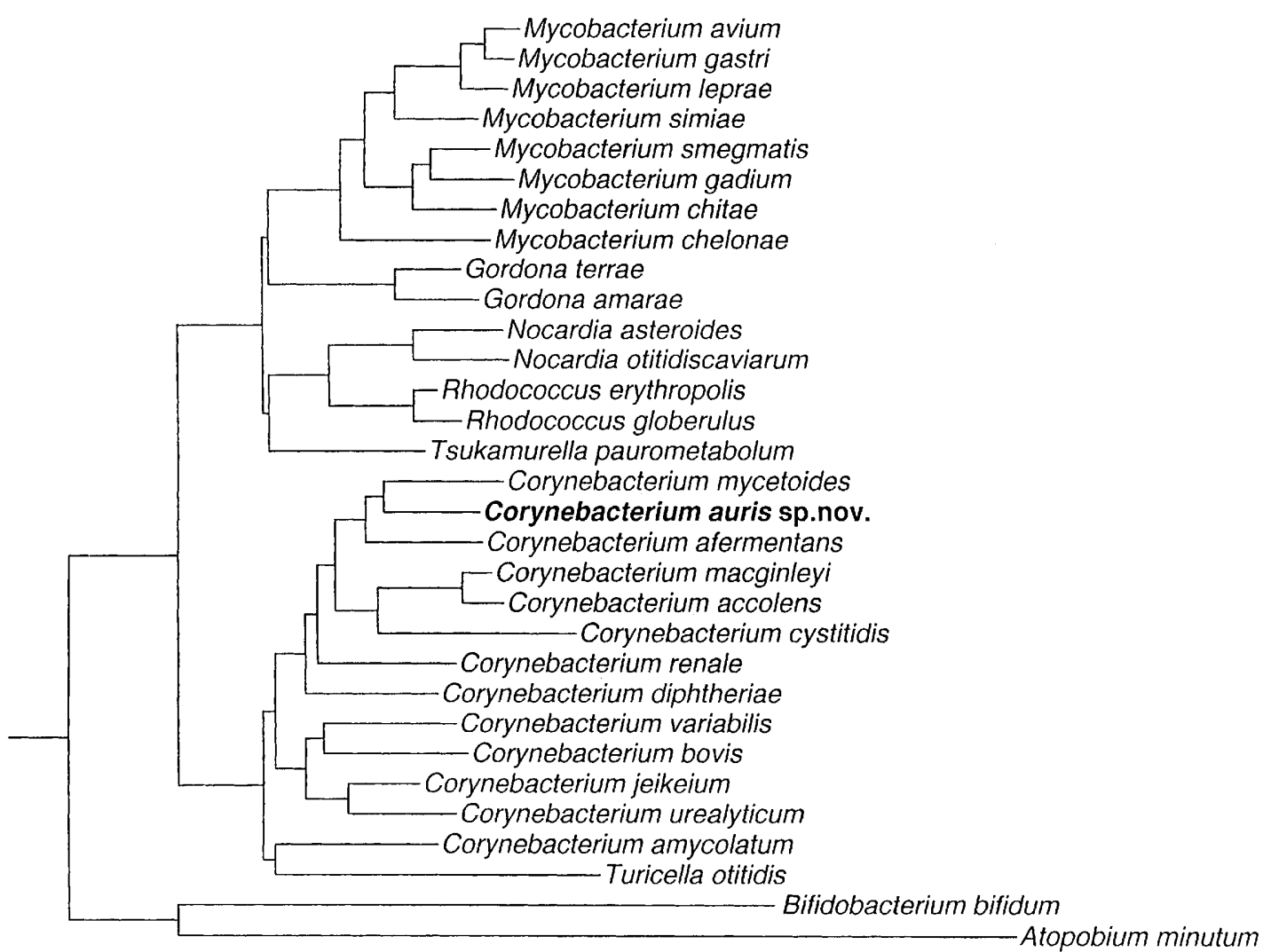

FIG. 1. Unrooted tree showing the phylogenetic position of $C$. auris within the high-G+C-content, gram-positive, rod-shaped bacteria.

strains which we studied. The characteristics which distinguish C. auris from related nonfermenting IGPR are shown in Table 3 .

The clinical significance of $C$. auris is not known, but so far this organism has been isolated exclusively from young patients with ear infections. In this respect $C$. auris resembles $T$. otitidis, whereas $C$. afermentans has been isolated mainly from blood $(5,9,17)$.

Description of Corynebacterium auris sp. nov. Corynebacterium auris (au'ris. L. gen. f. n. auris, of the ear). Cells are grampositive, nonmotile, non-spore-forming diphtheroids. Colonies are circular, convex, and dry, become slightly yellowish with time, and slightly adhere to agar, and the colony diameter ranges from 1.0 to $2.0 \mathrm{~mm}$ after $48 \mathrm{~h}$ of incubation on sheep blood agar at $37^{\circ} \mathrm{C}$. Catalase positive. Metabolism is respiratory. Acid is not produced from glucose, maltose, sucrose, mannitol, xylose, ribose, lactose, and glycogen. Nitrate is not reduced. Urea and esculin are not hydrolyzed. The CAMP reaction is positive. Pyrazinamidase, alkaline and acid phosphatases, esterase (C4), esterase lipase (C8), lipase (C14), leucine arylamidase, and phosphoamidase are produced.

The cell wall contains meso-diaminopimelic acid. Mycolic acids are produced. The predominant straight-chain saturated fatty acids are palmitic and stearic acids; oleic acid is the main unsaturated fatty acid. The DNA base composition is 68 to 74 mol\% G+C. Isolated from patients with ear infections. Type strain DMMZ 328 has been deposited in the German Collec-

TABLE 3. Biochemical characteristics of $C$. auris and related nonfermenting taxa

\begin{tabular}{|c|c|c|c|c|c|c|c|c|c|}
\hline Taxon & $\begin{array}{l}\text { Lipo- } \\
\text { philia }\end{array}$ & $\begin{array}{l}\text { Nitrate } \\
\text { reduction }\end{array}$ & $\begin{array}{l}\text { Urea } \\
\text { hydro- } \\
\text { lysis }\end{array}$ & $\begin{array}{l}\text { Pyrazin- } \\
\text { amidase } \\
\text { activity }\end{array}$ & $\begin{array}{c}\text { Alkaline } \\
\text { phosphatase } \\
\text { activity }\end{array}$ & $\begin{array}{l}\text { Acid pro- } \\
\text { duced from } \\
\text { glucose }\end{array}$ & $\begin{array}{l}\text { Acid pro- } \\
\text { duced from } \\
\text { maltose }\end{array}$ & $\begin{array}{l}\text { CAMP } \\
\text { reaction }\end{array}$ & Other traits \\
\hline C. auris & - & - & - & + & + & - & - & + & Dry, weak adherence to agar \\
\hline $\begin{array}{l}\text { C. afermentans subsp. } \\
\text { afermentans }\end{array}$ & - & - & - & + & + & - & - & V & See Table 1 \\
\hline $\begin{array}{l}\text { C. afermentans subsp. } \\
\text { lipophilum }\end{array}$ & + & - & - & + & + & - & - & V & \\
\hline C. propinquum & - & + & - & $\mathrm{V}$ & V & - & - & - & \\
\hline C. pseudodiphtheriticum & - & + & + & + & V & - & - & - & \\
\hline C. urealyticum & + & - & + & + & V & - & - & - & \\
\hline T. otitidis & - & - & - & + & + & - & - & + & See Table 1 \\
\hline
\end{tabular}

-, negative; + , positive; $\mathrm{V}$, variable. 
tion of Microorganisms, Braunschweig, Germany, as strain DSM 44122, and in the Culture Collection of the University of Göteborg, Göteborg, Sweden, as strain CCUG 33426. Strain DSM $44122^{\mathrm{T}}$ has the characteristics described above for the species and has a G+C content of $70 \mathrm{~mol} \%$.

\section{ACKNOWLEDGEMENTS}

We thank A. von Graevenitz for carefully reviewing the manuscript. C. Adler is acknowledged for determining the $\mathrm{G}+\mathrm{C}$ content.

This study was supported by the Hartmann Müller-Stiftung, Zurich, Switzerland, by the EMDO-Stiftung, Zurich, Switzerland, by the Hochschulverein, Zurich, Switzerland, and by EC grants BIO2-CT93-0119 and BIO2-CT94-3098.

\section{REFERENCES}

1. Collins, M. D., and C. S. Cummins. 1986. Genus Corynebacterium, p. 12661276. In P. H. A. Sneath, N. S. Mair, M. E. Sharpe, and J. G. Holt (ed.), Bergey's manual of systematic bacteriology, vol. 2. The Williams \& Wilkins Co., Baltimore.

2. Collins, M. D., M. Goodfellow, and D. E. Minnikin. 1982. A survey of the structures of mycolic acids in Corynebacterium and related taxa. J. Gen. Microbiol. 128:129-149.

3. Coyle, M. B., and B. A. Lipsky. 1990. Coryneform bacteria in infectious diseases: clinical and laboratory aspects. Clin. Microbiol. Rev. 3:227-246.

4. Felsenstein, J. 1989. PHYLIP-phylogeny inference package (version 3.2). Cladistics 5:164-166.

5. Funke, G. Unpublished data.

6. Funke, G., and A. Carlotti. 1994. Differentiation of Brevibacterium spp. encountered in clinical specimens. J. Clin. Microbiol. 32:1729-1732.

7. Funke, G., G. Martinetti Lucchini, G. E. Pfyffer, M. Marchiani, and A. von Graevenitz. 1993. Characteristics of CDC group 1 and group 1-like coryneform bacteria isolated from clinical specimens. J. Clin. Microbiol. 31:29072912.

8. Funke, G., G. E. Pfyffer, and A. von Graevenitz. 1993. A hitherto undescribed coryneform bacterium isolated from patients with otitis media. Med. Microbiol. Lett. 2:183-190.

9. Funke, G., S. Stubbs, M. Altwegg, A. Carlotti, and M. D. Collins. 1994. Turicella otitidis gen. nov., sp. nov., a coryneform bacterium isolated from patients with otitis media. Int. J. Syst. Bacteriol. 44:270-273.

10. Hollis, D. G., and R. E. Weaver. 1981. Gram-positive organisms: a guide to identification. Special Bacteriology Section, Centers for Disease Control, Atlanta.
11. Hutson, R. A., D. E. Thompson, and M. D. Collins. 1993. Genetic interrelationships of saccharolytic Clostridium botulinum types $\mathrm{B}, \mathrm{E}$ and $\mathrm{F}$ and related clostridia as revealed by small-subunit rRNA gene sequences. FEMS Microbiol. Lett. 108:103-110.

12. McLaughlin, J. C., K. L. Ruoff, V. H. Quenzer, T. L. Merlin, W. C. Thompson, and J. Fierro. 1992. A comparison of the identification of gram-positive aerobic bacteria by Biolog and Vitek, abstr. C-24, p. 424. In Abstracts of the 92nd General Meeting of the American Society for Microbiology 1992. American Society for Microbiology, Washington, D.C.

13. Mesbah, M., U. Premachandran, and W. B. Whitman. 1989. Precise measurement of the $\mathrm{G}+\mathrm{C}$ content of deoxyribonucleic acid by high-performance liquid chromatography. Int. J. Syst. Bacteriol. 39:159-167.

14. National Committee for Clinical Laboratory Standards. 1993. Methods for dilution antimicrobial susceptibility tests for bacteria that grow aerobically, 3 rd ed. Approved standard. NCCLS document M7-A3. National Committee for Clinical Laboratory Standards, Villanova, Pa.

15. National Committee for Clinical Laboratory Standards. 1993. Minimum inhibitory concentration (MIC) interpretive standards $(\mu \mathrm{g} / \mathrm{ml})$ for organisms other than Haemophilus, Neisseria gonorrhoeae, and Streptococcus pneumoniae. NCCLS document M7-A3. National Committee for Clinical Laboratory Standards, Villanova, $\mathrm{Pa}$.

16. Pitcher, D. G. 1983. Deoxyribonucleic acid base composition of Corynebacterium diphtheriae and other corynebacteria with cell wall type IV. FEMS Microbiol. Lett. 16:291-295.

17. Riegel, P., D. de Briel, G. Prévost, F. Jehl, H. Monteil, and R. Minck. 1993. Taxonomic study of Corynebacterium group ANF-1 strains: proposal of Conynebacterium afermentans sp. nov. containing the subspecies C. afermentans subsp. afermentans subsp. nov. and C. afermentans subsp. lipophilum subsp. nov. Int. J. Syst. Bacteriol. 43:287-292.

18. Saitou, N., and M. Nei. 1987. The neighbour-joining method: a new method for reconstructing phylogenetic trees. Mol. Biol. Evol. 4:406-425.

19. Sasser, M. Personal communication.

20. Schaal, K. P. 1985. Identification of clinically significant actinomycetes and rclated bacteria using chemical techniques, p. 359-381. In M. Goodfellow and D. E. Minnikin (ed.), Chemical methods in bacterial systematics. Academic Press, London.

21. Simonet, M., D. de Briel, I. Boucot, R. Minck, and M. Veron. 1993. Coryneform bacteria isolated from middle ear fluid. J. Clin. Microbiol. 31:16671668 .

22. Stackebrandt, E., and B. M. Goebel. 1994. Taxonomic note: a place for DNA-DNA reassociation and $16 S$ rRNA sequence analysis in the present species definition in bacteriology. Int. J. Syst. Bacteriol. 44:846-849.

23. von Graevenitz, A., G. Osterhout, and J. Dick. 1991. Grouping of some clinically relevant gram-positive rods by automated fatty acid analysis. APMIS 99:147-154. 